\title{
The Influence of Competence and Motivation Toward Employee Performance
}

\author{
R. Joko Sugiharjo
}

\begin{abstract}
This study determines the influence of competence and motivation on employee performance at PT Surya Toto Indonesia, tbk Cikupa. The object is the employees of Dry Body PT Surya Toto Indonesia, tbk Cikupa. This research was conducted on 154 respondents by using field research data collection method (field research). This study uses data collection techniques with surveys and direct observation The results of this study shows that the partial competence variables have a significant influence on employee performance PT Surya Toto Indonesia, tbk Cikupa. While the other results of this study is that the variable of motivation partially has no significant effect on employee performance PT Surya Toto Indonesia, tbk Cikupa.
\end{abstract}

Keywords: competence, motivation, employee performance

DOI: $10.7176 / \mathrm{JRDM} / 59-05$

Publication date:September $30^{\text {th }} 2019$

\section{INTRODUCTION}

\section{A. Background}

Every company or organization must have a target or goal to be achieved in a certain period. The target or objective will not be possible without adequate resources. Resources that have an important role in achieving company and organizational goals are human resources. Good human resources or employees can be seen one of them with the performance provided. Performance is basically what employees do that affects how much they contribute to the organization or company. Mangkunegara (2011) states that the term performance comes from the word job performance or actual performance, namely the quality and quantity of work achieved by an employee in carrying out their duties in accordance with the responsibilities given to him. Employee performance that is not good will directly affect the performance of the company so that it disrupts the stability of the company. If the problem is not resolved properly, it will disrupt the achievement of organizational goals. Therefore, various approaches are needed to overcome this problem. In this regard, an organization should pay more attention to the performance of its employees, especially to employees who have performance below the standards set by the organization concerned. Human resources that still have performance below the organization's standards, must continue to be fostered and directed to be able to support the success of the organization in achieving its goals. Because by increasing employee performance, it will ultimately improve organizational performance.

According to Wibowo (2010) stated that "motivation is an impetus for a series of processes of human behavior in achieving goals. While the elements contained in motivation include elements of arousing, directing, maintaining, showing intensity, being continuous and having a purpose ". If motivation is high, employee performance will increase.

The phenomenon that occurs at PT Surya Toto Indonesia, tbk Cikupa is employee performance caused by lack of competence and motivation. Following is the target percentage and realization data table of PT Surya Toto Indonesia, tbk Cikupa in the Dry Body section for the period of 2011-2015:

TABEL 1.1

Target and Achivement

\begin{tabular}{cccc}
\hline No & Year & Target & Achivement \\
1. & 2011 & $100 \%$ & $98 \%$ \\
2. & 2012 & $100 \%$ & $99 \%$ \\
3. & 2013 & $100 \%$ & $96 \%$ \\
4. & 2014 & $100 \%$ & $96 \%$ \\
5. & 2015 & $100 \%$ & $97 \%$ \\
\hline
\end{tabular}

Sources : Primery data :2011-2015

Based on the table above, PT Surya Toto Indonesia, tbk Cikupa, showed that in the last five years the results of employee performance declined. Every year the company has set a target of up to $100 \%$, but in 2011 the realization was only $98 \%$ and also until 2015 nothing reached $100 \%$. From the results of interviews and preresearch, this is thought to be caused by a lack of competence and motivation for employee performance. To prove competence, it can be seen from employee education data. The following table is based on the level of employee education 
TABEL 1.2

Employee Data

\begin{tabular}{lccccc}
\hline & & \multicolumn{4}{c}{ Employee education } \\
Study & $\mathbf{2 0 1 1}$ & $\mathbf{2 0 1 2}$ & $\mathbf{2 0 1 3}$ & $\mathbf{2 0 1 4}$ & $\mathbf{2 0 1 5}$ \\
Masters & 9 & 6 & 7 & 10 & 14 \\
& 325 & 288 & 314 & 326 & 435 \\
Diploma & 25 & 26 & 27 & 26 & 30 \\
SMA & 3.709 & 3.802 & 3.789 & 4.246 & 4.481 \\
SMP & 35 & 34 & 34 & 34 & 34 \\
SD & 13 & 45 & 44 & 44 & 6 \\
Total & 4.116 & 4.201 & 4.315 & 4.686 & 5.000 \\
\hline
\end{tabular}

Sumber : Annual Report PT Surya Toto Indonesia, tbk Cikupa

Based on the results of research by Suwardi and Utomo (2011), Hamid (2012), Murti and Veronika (2013), and Permansari (2013) found that work motivation significantly has a positive influence on employee performance. According to Lyle Spencer \& Signe Spencer (in Moeheriono, 2010) the underlying characteristics of a person relate to the effectiveness of the performance of individuals who have a causal relationship or as a cause-effect with criteria that are used as references, effective or excellent or superior performance in the workplace or in certain situations. The need theory proposed by Abraham Maslow explains the need for selfactualization. This self-actualization is a competency possessed by a human being. If the competence is good, then the performance will increase. Yudistira and Siwantara (2012) stated that competence has a positive and significant effect directly on employee performance. This is supported by research from Qamariah and Fadli (2011) also obtained the results of research that competence has a positive and significant effect on performance. Problem Formulation

In this study, does competency affect the performance of employees of PT Surya Toto Indonesia, tbk Cikupa?.

Does motivation affect the performance of employees of PT Surya Toto Indonesia, tbk Cikupa? Research

Objectives

To determine the effect of competence on employee performance at PT Surya Toto Indonesia, tbk Cikupa and to determine the effect of motivation on the performance of employees of PT Surya Toto Indonesia, tbk Cikupa.

\section{LITERATURE REVIEW}

A. Management

1. Definition of Management

The word management comes from the old French menagement, which means the art of carrying out and organizing. In addition, management comes from English, namely management which comes from the word manage, according to the Oxford dictionary which means to lead or make decisions in an organization. The term management which is translated from the word manage is usually associated with an action that regulates a group of people in a particular organization or institution in order to achieve certain goals. According to Manulang (Atik \& Ratminto, 2012) defines management as an art and science of planning, organizing, directing, compiling and controlling human resources to achieve the goals that have been set in advance. Meanwhile, according to G.R Terry (2010) explains that management is a typical process consisting of planning, organizing, mobilizing and controlling actions to determine and achieve goals through the use of human resources and other resources. Based on the notions of management described above, it can be concluded that management is a series of activities consisting of planning, organizing, directing control, and supervision by utilizing human resources and other resources to achieve a predetermined organizational goal.

B. Logical Framework

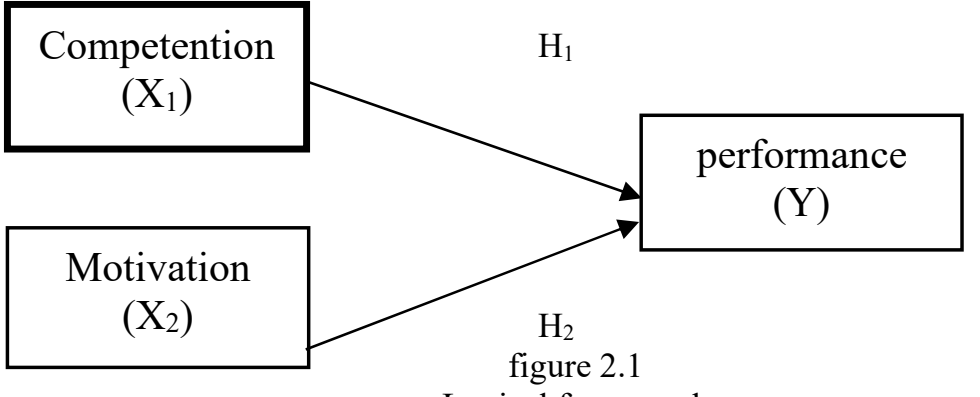

Logical framework 
A. Relationships Between Variables

Effect of Competence on Employee Performance

McClelland in Gaol (2014) defines competency as a fundamental characteristic possessed by someone who directly influences, or can predict, very good performance. Spencer (1993) in Abdullah (2014) also said that competency as an underlying characteristic of a person related to the effectiveness of performance in his work or basic characteristics of individuals who have a causal relationship or cause and effect with criteria used as a reference, effective or excellent or superior performance in the workplace or in certain situations.

2. Effect of Motivation on Employee PerformanceMotivation is formed from the attitude of an employee in dealing with work situations. Motivation is a condition that moves employees who are directed to achieve organizational goals (work goals). Mangkunegara (2013) also stated that motivation is "the condition or energy that drives employees who are directed or aimed at achieving the goals of the organization of the company". Then motivation can affect employee performance.

D. Hypothesis

Based on previous research and thought frameworks, the following hypotheses are made: 1. Alleged competence affects employee performance

2. It is suspected that motivation influences employee performance

\section{RESEARCH METHODS}

A. Research time and place

1. Research Time

The study was conducted in March-April until data and information needs were met. The research was carried out in stages, taken with surveys starting from the introduction, submission of proposals, filing permits, consulting, making questionnaires and processing thesis preparation data.

2. Research Sites

In this study, researchers took the location of the study at PT Surya Toto Indonesia Tbk. Jalan Aria Jaya Santika Km 21 No. 1, Cibadak, Bojong Village, Cikupa District, Bojong, Cikupa, Tangerang, Banten 15710.

B. Research Design

The design of this study was based on research methods. In this research, research design is used as a type of causal research. Causal research design is useful for analyzing relationships between a variable with other variables. Causal design examines the "causation" relationship. According to Sugiyono the causal method (2014) is to see the relationship of variables to the object under study is more causal, so that in his research there are independent variables (variables that affect) and dependent variables (variables that are affected).

In this study, researchers are interested in examining the independent variable, namely Competence and Motivation on a dependent variable, namely Employee Performance at PT Surya Toto Indonesia Tbk, Cikupa.

C. Variable Definition and Operations

Based on the title of the thesis proposal taken by the author that is "The Effect of Competence and Motivation on Employee Performance", the authors define each variable and make operational variables

1. Definition of Variables

The definitions of the variables that the researchers examined are as follows:

a. Independent variable (Independent variable)

According to Sugiyono (2014) independent variables or exogenous variables are variables that affect other variables or cause changes or the emergence of dependent variables, but are not influenced by previous variables. The independent variables in this researcher are: Competence (X1) and Motivation (X2).

b. Dependent variable in this study: Employee Performance (Y)

2. Variable Operationalization

The definition of a variable operation is a dimension given to a variable by giving meaning or specifying an activity or justifying an operation needed to measure the variable, Sugiyono (2014).

D. Measurement Scale

The measurement scale in this study uses a Likert Scale. Likert scale is a method used to measure attitudes, opinions and perceptions of a person or group of people about social phenomena. According to Sugiyono (2014) the Likert Scale is a psychometric scale commonly used in questionnaires, and is the scale most widely used in research in the form of surveys. The Likert scale uses five levels of answers, namely: 
TABEL 3.4

LIKERT

\begin{tabular}{ccc}
\hline answer & code & Score \\
Very agree & SS & 5 \\
agree & S & 4 \\
Netra & N & 3 \\
Not agree & TS & 2 \\
Very not agree & STS & 1 \\
\hline
\end{tabular}

Sources: Sugiyono (2014)

Population and Samples

1. Population

Sugiyono (2012) suggests the definition of population, namely: Population is a generalization area consisting of objects / subjects that have certain qualities and characteristics that are applied by researchers to be studied and then drawn conclusions. The population used in this study were employees of the Dry Body section of PT Surya Toto Indonesia Tbk, Cikupa, totaling 251 people. 2. Samples

According to Sugiyono (2012) the sample is "a portion of that population". The population is for example residents in certain regions, the number of employees in certain organizations, the number of teachers and students in certain schools and so on.

Determination of the sample used in this study uses a type of Probability Sampling technique, which is a sampling technique that provides equal opportunities for each element (member) of the population to be selected as a sample member (Sugiyono, 2012). The method used from the Probability Sampling in this study is Simple Random Sampling using the Slovin formula technique. Simple Random Sampling is a sampling of members of the population that is done randomly without regard to strata that exist in that population (Sugiyono, 2012)

F. Data Collection Techniques

In this study, the authors used a field research data collection method. This study uses data collection techniques with surveys and direct observation. The instrument used for data collection is interviews and questionnaires submitted to employees. For this type of data, there are two types of data in research, namely primary data and secondary data. Primary data is data obtained from the source directly using interviews, questionnaires, and surveys to the location of the research object, company guidelines, and other sources deemed relevant in this study. In this study, the authors used primary data obtained through surveys.

G. Data Analysis Methods

In this study, the authors used quantitative descriptive analysis, assisted by SPSS software. To facilitate research on the data collected, the data analysis methods used are:

1. Test Validity

Validity test is used to measure the validity of a questionnaire. A questionnaire is said to be valid if the questions on the questionnaire are able to reveal something that will be measured by the questionnaire. Significance test is done by comparing the value of $r$-count with $r$-table for degree of freedom $(d f)=n-2$, in this case $n$ is the number of samples (Ghozali, 2013). Testing is done using product moment correlation with the following formula:

$$
r_{x y}=\frac{n \cdot(\Sigma x y)-\left(\sum x \Sigma y\right) \cdot x}{\sqrt{\left[n \cdot \Sigma x^{2}-(\Sigma x)\right]\left[n \cdot \Sigma y^{2}-(\Sigma y)^{2}\right]}}
$$

Where :

rxy $=$ correlation index

$\mathrm{n}=$ number of samples

$\mathrm{x}=$ question score

$\mathrm{y}=$ total score

Provisions to declare valid or invalid is by comparing the results of the calculation of research data ( $\mathrm{r}$ arithmetic) with $r$ tables with the following criteria:

alpha: $5 \%$

n: 154

df: n-2 (154-2)

$r$ table: 0.1582

H. Analysis of Multiple Linear Regression

Sugiyono (2010) multiple linear regression analysis was used as a statistical analysis because this study was designed to examine the influential variables of the dependent variable (Leadership Style and Motivation) on the dependent variable (Employee Job Satisfaction). Where the variables used in this study are more than one. Then the formulation of the analysis model used in this study, namely: 
Information:

$$
\mathrm{Y}=\mathrm{a}+\mathrm{b}_{1} \mathrm{x}_{1}+\mathrm{b}_{2} \mathrm{x}_{2}+\mathrm{e}
$$

$\mathrm{Y}=$ Employee Performance

$\mathrm{a}=$ constant

$\mathrm{X} 1=$ Competence

$\mathrm{X} 2$ = Motivation

b1 b2 = Regression Direction Coefficient

$\mathrm{e}=$ Error $/$ confounding variable

\section{RESEARCH RESULTS AND DISCUSSION}

A. Overview of Research Objects

1. A History of PT. Surya Toto Indonesia, Tbk

Success began with CV SURYA, a dynamic trade in building materials. To achieve the best position in the sanitary industry since 1968 the company started by becoming an agent of TOTO LIMITED, Japan, one of the largest sanitary ware in the world.

B. Discussion of Research Results

1. Effect of Competence on Employee Performance

Based on the results of the $t$ test calculations show the results of the $t$ value of 4.483 and a significance value of 0.000 smaller than 0.05 . So it can be concluded that the competency variable has a positive and significant effect on employee performance at PT Surya Toto Indonesia, for the Dry Body section. This shows that if the competency possessed by employees is good, it will improve and affect employee performance. This is in line with the results of research conducted by Deriananda Jesistara Rayiki (2016) and Sandy Wulandari (2013) where competence has a positive and significant effect on organizational commitment. 2. Effect of Motivation on Employee Performance

Based on the results of the $t$ test calculations show the results of the $t$ value of 1.430 and a significance value of 0.155 greater than 0.05 . So it can be concluded that the motivation variable does not have a positive and significant effect on organizational commitment at PT Surya Toto Indonesia, for the Dry Body section. This is due to the motivation given to employees so that no matter how the efforts made by the organization in increasing motivation the results will not affect employee performance. This is not in line with the results of research conducted by Olivia Theodora (2015) and Dewi (2015) where motivation has a positive and significant effect on organizational commitment.

\section{CONCLUSION}

A. Conclusions

Based on the results of research and discussion, the conclusions in this study are as follows:

1. That competence has a significant effect on employee performance. This means that there must be an improvement and improvement in employee work discipline in order to be able to improve the performance of employees owned by PT Surya Toto Indonesia's employees, tbk Cikupa the Dry Body section.

2. That motivation does not significantly influence employee performance. This means that all efforts to provide or increase motivation by superiors and colleagues have been able to improve the performance of employees owned by employees of PT Surya Toto Indonesia, such as Cikupa Dry Body.

B. Suggestions

1. For companies Based on the conclusions above, the following suggestions can be given:

1. Employees should be able to identify problems at work, then employees should be able to correct work errors, and employees should have ideas or ideas from the results of their own thinking.

2. We recommend that employees are able to do the work according to the standards set and employees should be able to work well with coworkers with each other

2. For further researchers

The author submits for further research should carry out this research development by adding variables other than competence and motivation to influence employee performance. Because there are many other factors, namely work discipline, compensation, work environment and others that can affect employees or it would be better if conducting a pre-survey that is more focused in determining the phenomenon.

Thus the advice of researchers who can be considered by companies and subsequent researchers to improve employee performance.

\section{References}

AA. Anwar Prabu Mangkunegara. 2011. Manajemen Sumber Daya Manusia Perusahaan. Bandung : Rosda

AA. Anwar Prabu Mangkunegara. 2013. Manajemen Sumber Daya Manusia Perusahaan. Bandung : Remaja Rosdakarya 
Abdullah, Ma'ruf. 2014. Manajemen dan Evaluasi Kinerja Karyawan. Yogyakarta : Aswaja Pressindo

Ackah, David. 2014. Employee Motivation and Work Performance: A Comparative Study of Mining Companies in Ghana. Vol. 1, No.5:291-310.

Arifin, Muhammad. 2014. The Influence of Competence, Motivation, and Organisational Culture to High School Teacher Job Satisfaction and Performance. Vol. 8, No. 1:38-45.

Bangun, Wilson. 2012. Manajemen Sumber Daya Manusia. Jakarta : Erlangga

Dewi. 2015. Telaah Hubungan Kompetensi, Motivasi, dan Kinerja Karyawan. Vol. 9, No.1:50-55.

Dessler, Gary. 2010. Manajemen Sumber Daya Manusia. Jakarta : PT. Indeks

Gaol, Chr. Jimmy L. 2014. A to Z Human Capital Manajemen Sumber Daya Manusia. Jakarta : Grasindo

Ghozali, Imam. 2013. Aplikasi Analisis Multivariate Dengan Program SPSS, Edisis Ketujuh. Semarang : Badan Penerbit Universitas Diponegoro

Hasibuan, Malayu. 2012. Manajemen Sumber Daya Manusia. Jakarta : PT. Bumi Aksara

Hasibuan, Malayu. 2013. Manajemen Sumber Daya Manusia, Cetakan Ketujuh Belas. Jakarta : PT. Bumi Aksara L. Mathis, Robert - H. Jackson, John. 2011. Human Resource Management (edisi 10). Jakarta : Salemba Empat

Mensah, Elizabeth Boye Kuranchie dan Kwesi Amponsah-Tawiah. 2016. Employee Motivation and Work Performance: A Comparative Study of Mining Companies in Ghana. Vol. 9, No.2:255-309.

Ming, Tai Lee. 2011. The Influence of Workers' Competencies on Job Performance of Royal Malaysian Customs Department. Tesis. Pascasarjana Universiti Utara Malaysia.

Moeheriono. 2010. Pengukuran Kinerja Berbasis Kompetensi. Bogor : Penerbit Ghalia Indonesia

Moeheriono. 2012. Pengukuran Kinerja Berbasis Kompetensi, Edisi Revisi. Jakarta : PT. Raja Grafindo Persada

Mughbo dan Uju.S. 2013. The Influence of Motivation on Employees' Performance: A Study of Some Selected Firms in Anambra State. Vol. 2, No.7:134-151.

Nadeem. 2014. Impact of Employee Motivation on Employee Performance (A Case Study of Private Firms : Multan District, Pakistan). Vol. 36, No. 51:51-58.

Pasolong, Harbani. 2010. Teori Administrasi Publik. Bandung : Alfabeta

Rayiki. 2016. Pengaruh Kompetensi Pegawai dan Motivasi Kerja Terhadap Kinerja Pegawai Pada Klinik Bidan Iis Joni Jakarta. Vol. 16,No. 4:9-13.

Sastrohadiwiryo, B.S. 2012.Manajemen Tenaga Kerja Indonesia Pendekatan Administratif dan Operasional. Jakarta : PT. Bumi Aksara

Septi Winarsih, Atik \& Ratminto. 2012. Manajemen Pelayanan. Yogyakarta : Pustaka Pelajar

Sudarmanto. 2009. Kinerja dan Pengembangan Kompetensi SDM: Teori, Dimensi Pengukuran dan Implementasi Dalam Organisasi. Yogyakarta : Pustaka Pelajar

Sugiyono. 2010. Metode Penelitian Kuantitatif, Kualitatif \& RND. Bandung : Alfabeta

Sugiyono. 2012. Metode Penelitian Manajemen. Bandung : Alfabeta

Sugiyono. 2014. Metode Penelitian Kuantitatif, Kualitatif, dan Kombinasi (Mixed Methods). Bandung : Alfabeta Sunyoto, Danang. 2012. Teori, Kuesioner, dan Analisis Data Sumber Daya Manusia. Yogyakarta : CAPS

Sutrisno, Edy. 2010. Manajemen Sumber Daya Manusia. Jakarta : Kencana Prenada Media Group

Sutrisno, Edy. 2013. Manajemen Sumber Daya Manusia, Edisis Pertama. Jakarta : Kencana Prenada Media Group

Terry, George dan Leslie W. Rue. 2010. Dasar-dasar Manajemen, Cetakan Kesebelas. Jakarta : PT. Bumi Aksara

Theodora, Olivia. 2015. Pengaruh Motivasi Kerja Terhadap Kinerja Karyawan PT Sejahtera Motor Gemilang. Vol.3, No. 2:187-195.

Wibowo. 2010. Manajemen Kinerja, Edisi Ketiga. Jakarta : Rajawali Pers

Wibowo. 2013. Manajemen Kinerja. Jakarta : Rajawali Pers

Yuniarsih, Tjutju \& Suwatno. 2009. Manajemen Sumber Daya Manusia. Bandung : Alfabeta

Xiu dan Long Ye. 2014. Impacts of Teachers' Competency on Job Performance in Research Universities with Industry Characteristics: Taking Academic Atmosphere as Moderator. Vol.7, No.5:1283-1292.

Zaim et al. 2013. Analyzing The Effects of Individual Competencies on Performance : A Field Study in Services Industries in Turkey. Vol.7, No.2:67-77. 